\title{
Towards Identifying Peer Supervision Competencies for Graduate-level Occupational Therapy Students: A Scoping Review
}

\author{
Annie Murphy-Hagan \\ Washington University School of Medicine \\ Lauren E. Milton \\ Washington University School of Medicine
}

Follow this and additional works at: https://encompass.eku.edu/jote

Part of the Occupational Therapy Commons

\section{Recommended Citation}

Murphy-Hagan, A., \& Milton, L. E. (2019). Towards Identifying Peer Supervision Competencies for Graduate-level Occupational Therapy Students: A Scoping Review. Journal of Occupational Therapy Education, 3 (1). https://doi.org/10.26681/jote.2019.030104

This Original Research is brought to you for free and open access by Encompass. It has been accepted for inclusion in Journal of Occupational Therapy Education by an authorized editor of Encompass. For more information, please contact Linda.Sizemore@eku.edu. 


\title{
Towards Identifying Peer Supervision Competencies for Graduate-level Occupational Therapy Students: A Scoping Review
}

\begin{abstract}
In the occupational therapy (OT) profession, peer supervision groups are recommended for professional development, lessening attrition, and relieving stress. Peer supervision is under researched, thus competencies to support this practice are unknown. The purpose of this scoping review was to: (1) summarize the research knowledge around peer supervision to support evidence-based practice in OT, (2) map supervision competencies and key themes in the literature, and (3) isolate peer supervision competencies that may be especially relevant to graduate-level OT students. The long-term aim of this research is to develop a framework for evidence-based peer supervision training. Researchers investigated the question: What competencies related to peer supervision, supervision in OT clinical education, and supervision in allied health are relevant to the education of graduate-level OT students? Using a six-step methodological framework, a scoping review of empirical, conceptual, and grey literature was conducted. Studies relevant to peer supervision, supervision in OT clinical education, and supervision practices in allied health professions were searched and appraised, yielding 15 high quality studies. Competencies were extracted and mapped, resulting in the following OT peer supervision competencies: flexibility, professional enculturation, providing constructive feedback, psychosocial support, teaching, and clinical skill acquisition. Findings suggest OT peer supervision competencies center on skillful relationship abilities, as supervision skills are not innate, not dependent on clinical skill, and typically need to be taught. This study warrants the need for additional efforts around supervision practices.
\end{abstract}

\section{Keywords}

Peer supervision, occupational therapy students, occupational therapy education

\section{Creative Commons License}

(c) (i) (3)

This work is licensed under a Creative Commons Attribution-Noncommercial-No Derivative Works 4.0 License.

\section{Acknowledgements}

We would like to acknowledge the Innovations in Education Lab at the Program in Occupational Therapy at Washington University School of Medicine in St. Louis. 


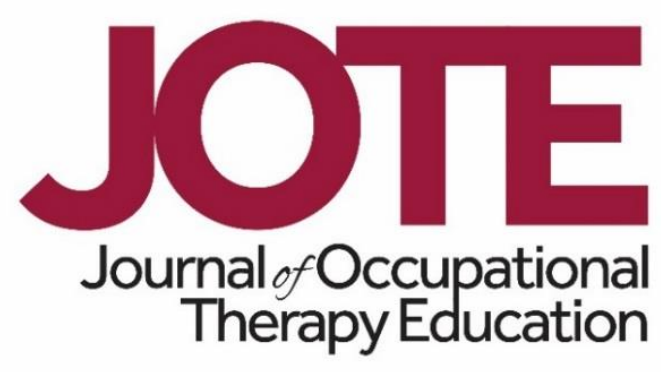

Volume 3, Issue 1

\title{
Towards Identifying Peer Supervision Competencies for Graduate-level
}

\section{Occupational Therapy Students: A Scoping Review}

\author{
Annie Murphy-Hagan, B.A., B.S. and Lauren Milton, OTD, OTR/L \\ Washington University \\ United States
}

\begin{abstract}
In the occupational therapy (OT) profession, peer supervision groups are recommended for professional development, lessening attrition, and relieving stress. Peer supervision is under researched, thus competencies to support this practice are unknown. The purpose of this scoping review was to: (1) summarize the research knowledge around peer supervision to support evidence-based practice in OT, (2) map supervision competencies and key themes in the literature, and (3) isolate peer supervision competencies that may be especially relevant to graduate-level OT students. The longterm aim of this research is to develop a framework for evidence-based peer supervision training. Researchers investigated the question: What competencies related to peer supervision, supervision in OT clinical education, and supervision in allied health are relevant to the education of graduate-level OT students? Using a six-step methodological framework, a scoping review of empirical, conceptual, and grey literature was conducted. Studies relevant to peer supervision, supervision in OT clinical education, and supervision practices in allied health professions were searched and appraised, yielding 15 high quality studies. Competencies were extracted and mapped, resulting in the following OT peer supervision competencies: flexibility, professional enculturation, providing constructive feedback, psychosocial support, teaching, and clinical skill acquisition. Findings suggest OT peer supervision competencies center on skillful relationship abilities, as supervision skills are not innate, not dependent on clinical skill, and typically need to be taught. This study warrants the need for additional efforts around supervision practices.
\end{abstract}




\section{INTRODUCTION}

Peer supervision occurs when participants with roughly the same level of training monitor, evaluate, and support one another (Akhurst \& Kelly, 2006; Golia \& McGovern, 2015; Spence, Wilson, Kavanagh, Strong, \& Worrall, 2001; Wimpenny, Forsyth, Jones, Evans, \& Colley, 2006). Peer supervision relationships are non-hierarchal and supportive, built around mutual responsibility, accountability, and desire for improvement (Spence et al., 2001). They create opportunities for meaningful learning through interactions with peers, encourage independence, as well as combat isolation, and may take place in dyadic or group contexts (Akhurst \& Kelly, 2006; Golia \& McGovern, 2015). In training contexts, this peer relationship is often supplemental to supervision provided by a senior professional (Akhurst \& Kelly, 2006; Golia \& McGovern, 2015). Peer supervision may be highly structured, such as when used as a teaching technique, or may organically develop between peers out of a need for mentorship and support (Golia \& McGovern, 2015).

The benefits of peer supervision in some health professions is well established. Counseling, psychotherapy, and social work frequently make use of group peer supervision for purposes of professional development including mitigating stress, building competency, and strengthening practice of ethical standards among young professionals (Akhurst \& Kelly, 2006; Golia \& McGovern, 2015; Spence et al., 2001). Benefits of peer supervision in health care include professional enculturation, the process in which one learns the ways and norms of the profession, and professional development (Borders, 1991). Peer supervision may provide an avenue to model and practice both supervision and clinical skills (Akhurst \& Kelly, 2006; Borders, 1991; Counselman \& Weber, 2004; Golia \& McGovern, 2015; Thomasgard \& Collins, 2003; Žorga, Dekleva, \& Kobolt, 2001). Despite the purported benefits, peer supervision is under researched (Akhurst \& Kelly, 2006; Borders, 1991; Bussey-Jones et al., 2006; de Oliveira, de Franca Carvalho, Cespedes, de Oliveira, \& Le Sueur-Maluf, 2015; Golia \& McGovern, 2015; Lord et al., 2012; Thomasgard \& Collins, 2003). Little is known about the use of peer supervision in OT, and to date, there are no published studies of peer supervision among graduate-level OT students.

Where OT peer supervision studies do exist, they rarely offer guidelines, training, or curriculum material for putting peer supervision into practice. Given this specific topic is not extensively researched or developed, a scoping review of literature is indicated (Mays, Roberts, \& Popay, 2001). The purpose of this scoping review was to:

(1) Summarize the research knowledge around peer supervision to support evidence-based practice in OT.

(2) Map peer supervision competencies and key themes in the literature.

(3) Isolate peer supervision competencies that may be especially relevant to graduate-level OT students.

The long-term aim of this research is to develop a framework for evidence-based peer supervision training for graduate-level OT students. 


\section{METHODS}

A scoping review of the literature was conducted to address the purpose and objectives of the study. According to Mallidou et al. (2017), based on the work of Arksey and O'Malley (2005) and further discussed by Levac, Colquhou and O'Brien (2010), a scoping review involves six stages: (1) formulating the research question; (2) identifying relevant studies; (3) selecting the literature (an iterative process); (4) charting the data; (5) collating, summarizing, and reporting the results; and (6) developing a knowledge translation plan consulting interested stakeholders.

\section{Formulating the Research Question}

The term supervision was selected to place emphasis on the evaluative role of the relationship over other roles: i.e. professional networking (mentoring), instruction (tutoring), or expertise (consultation). Additionally, peer supervision is specifically noted for an emphasis on emotional well-being of the supervisee (Golia \& McGovern, 2015) and the role of the relationship as a mechanism for development (Thomasgard \& Collins, 2003). Alternative terms for peer supervision are peer mentoring (BusseyJones et al., 2006), peer mentoring groups (Lord et al., 2012), peer supervision groups (Thomasgard \& Collins, 2003), peer tutoring (de Oliveira et al., 2015), peer consultation (Borders, 1991), dual supervision (Akhurst \& Kelly, 2006), and planned, facilitated, or ad hoc peer supervision (Golia \& McGovern, 2015).

As there are no peer supervision studies among graduate-level OT students to date, this scoping review covered the literature in adjacent domains: peer supervision, supervision in OT clinical education, and supervision practices for students in allied health disciplines. For this scoping review, the researchers adopted the following definitions for these adjacent domains. Peer supervision was defined as "any facilitated, planned or ad hoc interactions with colleagues of similar experience levels, [. . . . in both dyadic and group contexts, for the purposes of clinical training, professional development, and mutual aid and affinity" (Golia \& McGovern, 2015, p. 635). Based on the American Occupational Therapy Association (AOTA) Commission on Education (COE) guidelines, supervision in OT clinical education referred to both mandatory OT clinical training (known as fieldwork) as well as education training experiences involving graduate-level OT students evaluating, treating, and working with patients (AOTA, 2012). Finally, other allied health supervision practices referred to the training of students and entry-level professionals in nursing, medicine, social work, psychology, and physical therapy ("What is allied health," n.d.).

Therefore, this scoping review addressed the research question: What competencies related to peer supervision, supervision in OT clinical education, and supervision in allied health are relevant to the education of graduate-level OT students?

\section{Identifying Relevant Studies}

A literature search was conducted through the Cumulative Index to Nursing and Allied Health Literature (CINAHL), Google Scholar, and the following OT journals: American Journal of Occupational Therapy, British Journal of Occupational Therapy, and 
Australian Occupational Therapy Journal. Additional search methods, such as hand searching, were also employed.

Research on clinical supervision practices is scarce, and therefore few indexed subject headings solely pertain to the focus of this paper. Thus, subject headings were used for title and abstract searches as well as identifying additional indexed subheadings (Mallidou et al., 2017). Search terms included, but were not limited to: adult learning, clinical competence, clinical education, clinical reasoning, clinical supervision, communication, education, education models, feedback, fieldwork education, grounded theory, internship and residency, knowledge, learning, mentors, occupational therapy, peer mentorship, peer supervision, professional development, professional identity, professional role, program evaluation, reflective practice, skill acquisition, stress, students, student performance appraisal, teaching, e-learning modules, training, translational medical research, supervisors, and supervision.

\section{Select the Literature (an Iterative Process)}

The literature around education and supervision is rarely of a quantitative or randomized design since educational contexts are impossible to control (Berliner, 2002) and relevant results are often descriptive. Therefore, it was determined that evidence should be gathered "from a broader range of study designs" (Khan, Kunz, Kleijnen, \& Antes, 2003, p. 120). Few restrictions were applied to the inclusion/exclusion criteria. Publications could be of any date but had to be written in English. More specifically, each publication had to meet the following requirements:

(1) Be an empirical or conceptual research publication or a document from the grey literature, defined as literature "produced and distributed on all levels of government, academics, business and industry in electronic and print formats not controlled by commercial publishing" (Farace \& Frantzen, 1998, p. iii).

(2) The key focus of the article had to revolve around concepts of peer supervision, supervision of allied health professionals, or supervision in OT clinical education.

A single researcher gathered, collated and synthesized the evidence. A research librarian guided the literature search. Literature was gathered and analyzed from March to September 2016. An OT educational researcher mentored the process, including weekly meetings.

\section{Charting the Data}

The Preferred Reporting Items for Systematic Reviews and Meta-Analyses flow diagram (PRISMA; Moher, Liberati, Tetzlaff, Altman, \& The PRISMA Group, 2009) was used to organize the literature search and identify studies for data extraction. All 34 full text articles were read and classified by the researcher according to each article's design, framework/theory, research question/study objectives, methods, measures, and study findings. Study results that related to supervision competencies were coded and entered into NVivo 11, a computer-assisted qualitative data analysis system. Code queries were run to compare and contrast themes in the data, resulting in a Venn diagram. 


\section{Collating, Summarizing, and Reporting the Results}

Studies were classified as high, moderate, or low quality (see Table 1). This ranking system was adapted by the author based on a similar analysis method used in Kahn et al. (2003, p. 120). The final selected literature included those from empirical and conceptual research as well as documents from grey literature. Table 1 describes how sources were ranked in terms of high, medium, or low quality for empirical, conceptual, and grey literature.

Data extracted from the records were purpose, design/approach, methods (including outcome measures where applicable), and results. High quality sources were placed into an evidence table (see Appendix A). The results sections of the evidence table were coded for competencies by a member of the research team. Such competencies included those explicitly stated and implied (such as unhelpful supervision behaviors, positive supervisee behaviors, and benefits of supervision). Similar competencies were grouped together and the subject of the source origin (peer supervision, OT clinical education, allied health professions) was noted.

Table 1

Quality Classification of the Literature

\begin{tabular}{|c|c|c|c|}
\hline Literature Type & High & Moderate & Low \\
\hline Empirical & $\begin{array}{c}\text { Study showed } \\
\text { scientific rigor (i.e. } \\
\text { peer-review } \\
\text { publication); } \\
\text { supervision practices } \\
\text { were the main focus }\end{array}$ & $\begin{array}{c}\text { Study conducted }> \\
20 \text { years ago; study } \\
\text { showed less rigor } \\
\text { (i.e. non-peer review } \\
\text { publication); study } \\
\text { was supportive of a } \\
\text { larger one included } \\
\text { in the 'high' quality } \\
\text { category }\end{array}$ & $\begin{array}{l}\text { Same criteria as } \\
\text { medium quality but } \\
\text { focus of study was } \\
\text { more tangentially } \\
\text { related to } \\
\text { supervision practices }\end{array}$ \\
\hline Conceptual & $\begin{array}{l}\text { Structured literature } \\
\text { review; supervision } \\
\text { practices were the } \\
\text { main focus }\end{array}$ & $\begin{array}{l}\text { Review published }> \\
20 \text { years ago; focus } \\
\text { was on personal } \\
\text { experiences of } \\
\text { supervision }\end{array}$ & $\begin{array}{l}\text { Same criteria as } \\
\text { medium quality but } \\
\text { focus of study was } \\
\text { more tangentially } \\
\text { related to } \\
\text { supervision practices }\end{array}$ \\
\hline Gray & $\begin{array}{l}\text { White paper; official } \\
\text { AOTA published } \\
\text { statement; expert } \\
\text { opinion backed by } \\
\text { literature review }\end{array}$ & $\begin{array}{c}\text { Focus was on } \\
\text { program } \\
\text { development only; } \\
\text { expert opinion that } \\
\text { was not supported } \\
\text { by a literature review }\end{array}$ & $\begin{array}{l}\text { Same criteria as } \\
\text { medium quality but } \\
\text { focus of study was } \\
\text { more tangentially } \\
\text { related to } \\
\text { supervision practices }\end{array}$ \\
\hline
\end{tabular}

Note: Classification of empirical, conceptual, and gray literature as high, medium, or low 


\section{Developing a Knowledge Translation Plan}

Clusters of competencies were placed into the Venn diagram according to subject of source origin. If themes were pertinent to more than one domain, then they were placed in the appropriate overlapping category. The purpose was to conceptualize an OT peer supervision construct consisting of competencies that appeared across the three types of supervision literature. Interested stakeholders including current fieldwork educators, practicing clinicians, and academic fieldwork coordinators were consulted. Ultimately, results will be used to develop a framework for an original peer supervision training that can serve the needs of student clinical education experiences.

\section{RESULTS}

Of the 51 articles reviewed, 34 articles met the eligibility criteria. These 34 articles included: 2 articles on peer supervision or group mentoring, 17 articles on OT clinical education, and 15 articles from allied health professions. Data was extracted from each of the 34 articles to determine quality and relevance to research question. This resulted in a final list of 15 high quality articles: 2 articles on peer supervision or group mentoring, 5 articles on OT clinical education, and 8 articles from allied health professions. Figure 1 outlines the literature search and selection process based on the PRISMA (Moher et al., 2009), along with the addition of literature quality ratings.

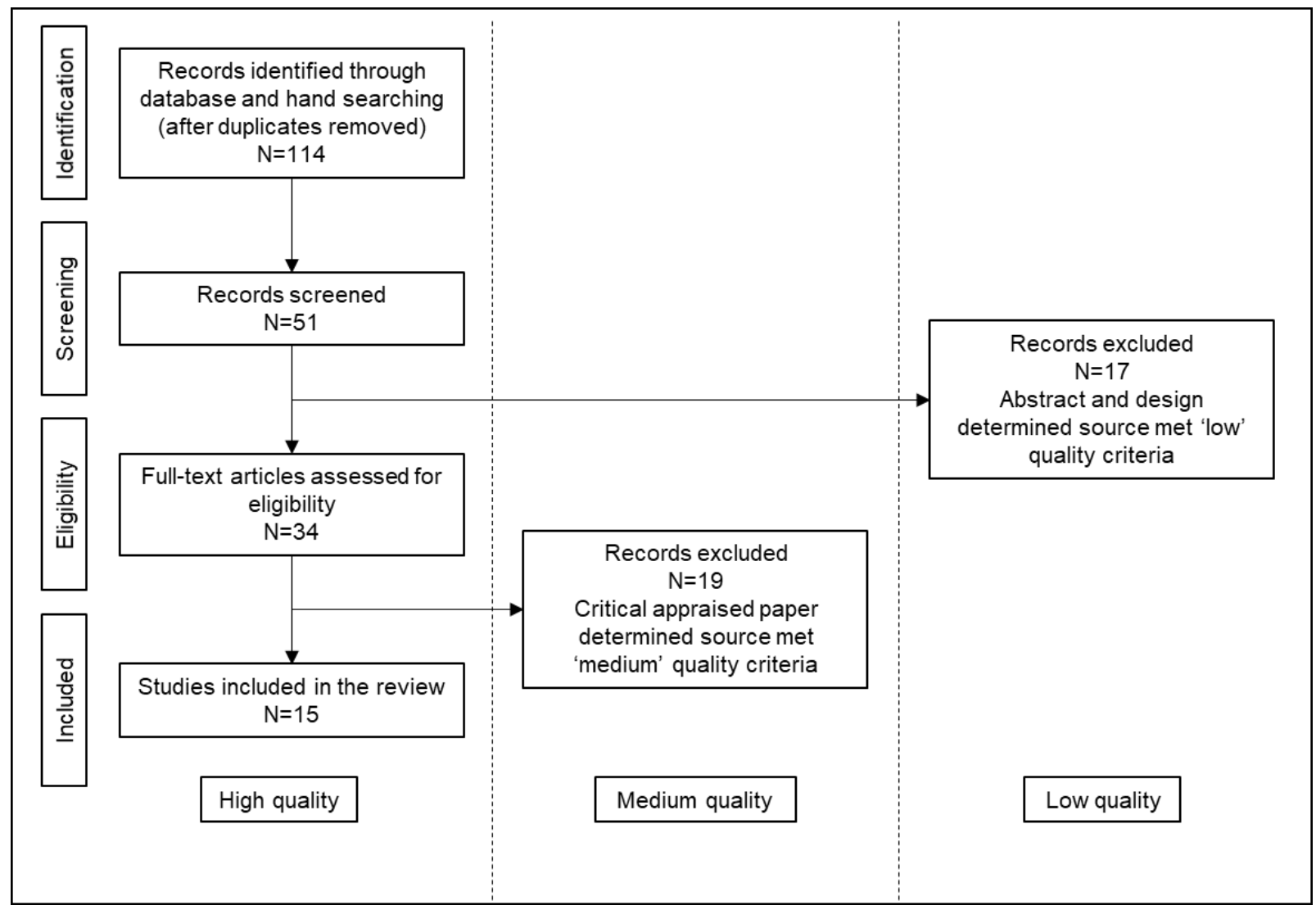

Figure 1. A flow diagram of the study selection process based on PRISMA (Moher, Liberati, Tetzlaff, Altman, \& The PRISMA Group, 2009), expanded to show associated quality ratings. 
Sources were divided according to subject and literature type (see Tables 2 and 3). Empirical literature was equally distributed across all categories, while conceptual literature was most often classified as medium quality. Literature on OT clinical education was included the most, but only approximately $20 \%$ of studies were found to be high quality. The scarcity of quality peer supervision studies suggested that peer supervision is an under researched resource for enhancing learning experiences.

Table 2

Quality Ranking by Literature Type

\begin{tabular}{|l|c|c|c|}
\hline Literature Type & High & Moderate & Low \\
\hline Empirical & 9 & 9 & 9 \\
\hline Conceptual & 4 & 9 & 5 \\
\hline Grey & 2 & 1 & 3 \\
\hline
\end{tabular}

Table 3

Quality Ranking by Subject Type

\begin{tabular}{|l|c|c|c|}
\hline Literature Type & High & Moderate & Low \\
\hline Peer Supervision & 2 & - & - \\
\hline $\begin{array}{l}\text { OT Clinical } \\
\text { Education }\end{array}$ & 5 & 12 & 9 \\
\hline Allied Health & 8 & 7 & 8 \\
\hline
\end{tabular}

The 15 high quality records included in the final evidence table (see Appendix A), provided an accessible format for directly comparing study results. Results were both quantitative and qualitative and typically centered on the role of the supervisor/supervisee, benefits of supervision, effective supervision practices, competencies and skills, common themes, and recommendations for practice.

\section{Charting Supervision Competencies}

Supervision competencies were mapped using a Venn diagram, as seen in Figure 2, divided into spheres according to literature subject: peer supervision, supervision in OT clinical education, and supervision in allied health. In total, 10 of the 15 studies contributed to competencies in all three of these subject domains and contributed to the construct of OT peer supervision. 


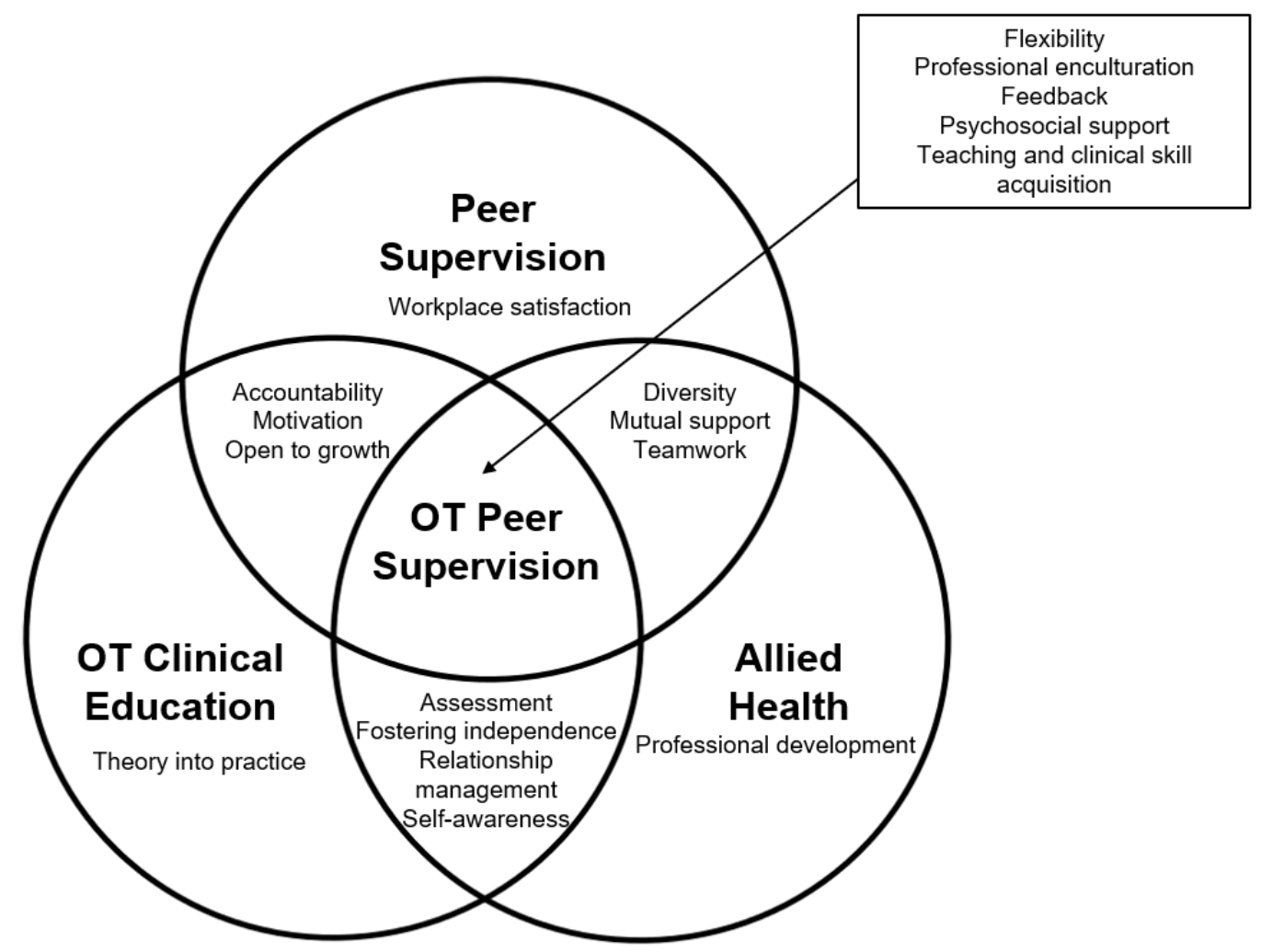

Figure 2. A Venn diagram mapping of supervision competencies specific to peer supervision, OT clinical education, allied health supervision, and OT peer supervision.

Competencies related to OT peer supervision included flexibility, professional enculturation, providing constructive feedback, psychosocial support, and teaching and clinical skill acquisition. Secondary competencies were identified where other domains overlapped. For instance, both OT clinical education and allied health literature sources valued supervision relationships focused on assessment and quality control, fostering independence, prioritizing the relationship, relationship management, and selfawareness. Allied health and peer supervision literature discussed the importance of diversity, mutual support and teamwork. Occupational therapy clinical education and peer supervision groups emphasized openness to growth, accountability and motivation. Finally, there were some themes specific to singular domains. Allied health literature discussed the importance of supervision and professional development, whereas OT clinical education literature stressed the role of the supervisor in putting theory into practice. Finally, peer supervision sources placed a high value on the role of peer supervision in increasing workplace satisfaction.

Mapping the competencies revealed a continuum of competencies across the supervision literature. Evidence regarding each competency provides a conceptual framework for the competency. This framework has the potential to support a future training on peer supervision competencies in OT education. 
Flexibility. Three studies focused on flexibility ( 2 conceptual, 1 empirical; Martin, Copley, \& Tyack, 2014; Milner \& Bossers, 2005; Spence et al., 2001). The literature described supervision as a process and a relationship that must be consistently revisited and revised. Spence et al. (2001) wrote that supervisors have a responsibility to "address process issues within the supervisory relationship; seeking feedback and regularly evaluating own performance as a supervisor" (p. 142). Additional recommendations included:

- "Being flexible; adapting style of supervision to the specific needs of the supervisee and the type of casework" (Spence et al., 2001, p. 142).

- "Deciding on the most suitable type of supervision" because "the preferred type of supervision tends to vary according to the discipline" (Martin et al., 2014. p. 202).

Professional enculturation. Four studies focused on professional enculturation (1 grey, 2 empirical, 1 conceptual; Abedin et al., 2012; Fone, 2006; Lord et al., 2012; Pfund et al., 2013). It was recommended that supervisors "make explicit institutional and discipline-specific norms, standards, and expectations" (Abedin et al., 2012, p. 276). Other crucial components of supervision success included:

- The ability to "communicate effectively across diverse dimensions including varied backgrounds, disciplines, ethnicities, positions of power, and styles" (Abedin et al., 2012, p. 276).

- "Improv[ing] understanding of individual differences and cultures, identify concrete strategies for addressing issues of diversity" (Pfund et al., 2013, p.27).

- "Creation of a culture and an environment that is overtly supportive of ongoing shifting of personal and professional skills" (Fone, 2006, p. 282).

Feedback. Seven studies focused on constructive feedback (2 conceptual, 5 empirical; Fleming et al., 2013; Cohen, Steele \& Ross, 1999; Martin et al., 2014; Milner \& Bossers, 2005; Saucier, Paré, Côté, \& Baillargeon, 2012; Spence et al., 2001; Sweeney, Webley \& Treacher, 2001). As Cohen et al. (1999), surmised, the supervisor is challenged to "[. . .] provide feedback in a wise manner, that is, in a manner that discourages expectations and attributions of racial bias and that minimizes stereotype threat" ( $p$. 1303). A qualitative study that examined relationships among supervisors and supervisees during fieldwork recommended, "feedback should be clear, owned, regular, balanced and specific" and that "both parties need to assume responsibility in the way in which they seek, receive and respond to feedback" (Sweeney et al., 2001, p. 429). Such feedback:

- Focuses "on specific, concrete examples of supervisee's clinical activities" (Spence et al., 2001, p. 142).

- Is "balanced with both positive and constructive elements" (Sweeney et al., 2001; Martin et al., 2014, p. 203).

- Identifies the "supervisee's strengths and weaknesses relating to core skills, knowledge, attitudes, and competencies, and developing goals for improvement" (Spence et al., 2001, p. 142).

- "Takes into account the [supervisee's] level of professional maturation" (Saucier et al., 2012, p. 1999). 
Psychosocial support. Five studies focused on psychosocial support (1 grey, 1 conceptual, 3 empirical; Abedin et al., 2012; Fleming et al., 2013; Lord et al., 2012; Saucier et al., 2012; Spence et al., 2001). Peer supervision groups offered "opportunities for mutual learning, support, encouragement, advice, and information sharing, resulting in personal growth and development" by allowing "peers at the same professional level to dialogue in a safe environment" (Lord et al., 2012, p. 380). Crucial components of creating a safe environment included:

- "Being respectful and empathetic; validating, demonstrating concern for supervisee welfare; showing an interest in and listening to supervisee's input and issues" and "facilitating the processing of emotional material" (Spence et al., 2001, 142).

- "[. . . ] establishment of a relationship based on mutual trust" (Saucier et al., 2012, p.1198).

- Understanding "how individual differences and cultures influence supervisory relationships" (Abedin et al., 2012, p. 276).

- Making a practice of "accounting for biases and prejudices" (Fleming et al., 2013, p. 1005), especially in high-stakes communication situations such as giving and receiving feedback.

- Providing "work-life balance guidance," emphasizing the role of self-reflection in improving relationships, and empowering the mentee "to seek guidance and help from other scholars at their level of training" (Abedin et al., 2012, p. 276).

Teaching and clinical skill acquisition. Eight studies focused on teaching and clinical skill acquisition (3 conceptual, 5 empirical; Berk, Berg, Mortimer, Walton-Moss, \& Yeo, 2005; Chipchase et al., 2012; Fone, 2006; Hall \& Cox, 2009; Milner \& Bossers, 2005; Saucier et al., 2012; Spence et al., 2001; Sweeney et al., 2001). Fone (2006) emphasized the importance of mutually deciding on "the need to change a certain skill, behavior" and "identify the learning style of the supervisee to maximize his or her ability to learn new skills" (p. 282). This may be achieved through a supervision contract, as suggested by Sweeney et al. (2001), that "provides a concrete and objective means of measuring and documenting progress" and that can "be reviewed and renegotiated at regular intervals by both parties" (p. 429). Other recommendations included:

- "Using a variety of instructional methods, including information giving, providing guidance for reading modelling, audiovisual demonstration, observation of supervisee practice (direct, taped, case-descriptions, reports), and providing opportunities for practice and problem solving" (Spence et al., 2001, p. 143).

- Recommending "appropriate resources (e.g., experts, electronic contacts, source materials)" and challenging the supervisee to "expand his or her abilities" (Berk et al., 2005, p. 67).

- Acknowledging "Supervisors should receive support and training for their important role within the supervision relationship" (Hall \& Cox, 2009, p. 289), because "[. . . ] preparation for the clinical supervision process influences understanding and experience of clinical supervision" (Hall \& Cox, 2009, p. 286). 


\section{DISCUSSION}

Studies emphasized the importance of understanding supervisees as active participants in the supervision process with roles and responsibilities (Sweeney et al., 2001), suggesting there may be value in giving students supervision experiences prior to entering practice (Bassett \& Lloyd, 2001; Leonard \& Corr, 1998). There is a need to develop a systematic approach for teaching OT supervision skills (Fone, 2006; Sweeney et al., 2001), especially since, as Martin et al. (2014) suggests, the supervision relationship itself is the prominent factor in effective supervision. The specific function of peer supervision is to provide feedback that aids in clinical skill acquisition. This is achieved through skillful relationship building, including therapeutic elements of flexibility and psychosocial support. The outcome is occupation-based; students are encultured into occupations of the profession-supervising others and receiving supervision.

\section{Flexibility}

Peer supervision relationships reflect a dynamic process in which supervision practices are reflected on and adopted to meet the unique needs of the individual and environmental context. The "Philosophy of Occupational Therapy Education" espouses the belief that "students are viewed as occupational beings who are in dynamic transaction with the learning context and teaching-learning process" (AOTA, 2015, p.1). This exchange between the students and the occupational environment demands fluidity of both content and support. Therapeutic contexts are dynamic and multivariate, and thus OT education stresses theory over regimented approaches. Likewise, peer supervision is dynamic, forming in response to the learner and environment.

\section{Professional Enculturation}

The "Philosophy of Occupational Therapy Education" states, "Occupational therapy education is the process by which practitioners acquire their professional identity" (AOTA, 2015, p.1). Peer supervision creates opportunities for learning from and collaborating with others. It allows for both modeling and practicing of culturally responsive ways of communicating and behaving in accordance with professional norms and standards. Through collaboration, students synthesize diverse perspectives and integrate these into their professional identity. The "Occupational Therapy Model Curriculum" discusses the concept of OT education's implicit curriculum, by which students are guided in forming their personal, professional identity (Berg et al., 2009). The implicit curriculum consists of the "rites, patterns of relating, artifacts, spaces, and social organization-the culture-of the program" (Berg et al., 2009, p.9). Peer supervision is a part of the meaningful patterns of relating. How students learn to monitor, evaluate, and support one another, is a part of the professional socialization process. Just as occupation is both a means and an outcome of therapy, peer supervision can be a means and an outcome of OT education.

\section{Feedback}

The literature endorsed the notion that providing and receiving feedback was a specific skill that is learned (Sweeney et al., 2001). Effective feedback is specific and context sensitive and posed with a clear outcome or instruction in mind (Martin et al., 2014; 
Spence et al., 2001; Sweeney et al., 2001). The "Philosophy of Occupational Therapy Education" included values of life-long learning through clinical reasoning, assessment, and reflective practice (AOTA, 2015). Peer feedback can contribute to the selfassessment process, by allowing peers to identify areas of growth and opportunity. This practice connects with lifelong learning, a fundamental value of OT education. While peer-teaching and peer-review are promoted as strong methods for achieving learning and ability-based outcomes (Berg et al., 2009), specific guidelines for effective peer feedback are not offered.

\section{Psychosocial Support}

Peer supervision provides an opportunity for relationship-based learning in which peers engage in developmental challenges in a safe and caring learning environment. The "Occupational Therapy Model Curriculum" discussed a nurturing approach to teaching in which the teacher takes a holistic view of the learner's context and offers safety and encouragement throughout (Berg et al., 2009). This approach endorses the notion that psychological support and safety are requisite to significant learning. Indeed, significant learning stems from the relationships within the learning environment. Fink classified this concept as the human dimension of significant learning, in which "[ . . .] when one learns about one's Self, one almost inevitably learns about others, and vice versa" (Fink, 2003, p. 47). Psychosocial support in peer supervision relationships creates an environment in which relationship-based learning is both a means and an outcome. The essence of this notion comes from what is already known from therapy, that "it is the relationship that becomes the mediator for enhanced professional development for the clinician [. . .]" (Thomasgard \& Collins, 2003, p. 307). Hence, peer supervision serves a purpose beyond instruction in improving therapeutic techniques but informs students in the ways and being a professional.

\section{Clinical Skill Acquisition}

Peer supervisors are well-positioned to facilitate skill acquisition through provision of resources, collaborative learning, and mutual goal setting. As suggested by Borders (1991), "novices speak the same language and model achievable skill levels, increasing self-efficacy and motivation to learn" (p. 248). Taken together, the evidence suggested that OT peer supervision competencies centered on skillful relationship abilities. Such supervision skills are not innate, not dependent on clinical skill, and typically need to be taught (Stutz-Tannenbaum \& Hooper, 2009).

Clinical learning experiences can be enhanced by having students try out the role of fieldwork educator and assume more supervision responsibilities in clinical learning experiences. Furthermore, the "Philosophy of Occupational Therapy Education" (AOTA, 2015) asserts that students should be dynamic actors in the teaching-learning process, participating in self-appraisal, professional identity, and development. Thus, there exists a need to develop a structured approach to training OT peer supervisors. A valuable next step would be to elicit opinions of key stakeholders (i.e. students) engaged in clinical education scenarios where peer assessment and collaboration is practiced. 


\section{Limitations}

This scoping review would have been strengthened by additional perspectives. One of the authors is a peer supervisor in a student-run clinic. This lens may have predisposed the author to value certain data sets over others. A single author coded the literature for supervision competencies, which likely introduced an implicit bias. Direct quotes and evidence were placed directly into the evidence table to prevent misinterpretation of results. However, the creation of supervision competency themes may have been biased by the process.

Interchangeable terms for "peer supervision" likely limited the quality of results as well. Many of the articles used terms such as "mentorship" but met the researcher's operative definition of peer supervision. This meant that each article had to be read to determine if the subject fit the operative definition. Typically, peer supervision is offered in conjunction with supervision from a senior authority. At times it was difficult to parse out the actions and competencies of the senior supervisor versus the peer supervisor.

Throughout the scoping review the researchers improved search terms, techniques, and identified relevant articles more readily. As a result, some literature that would have met the inclusion criteria was not identified until after the scoping review had been completed. Some of these newer sources were cited extensively in the introduction of the article, including: Akhurst and Kelly, 2006; Borders, 1991; Bussey-Jones et al., 2006; Counselman and Weber, 2004; Golia and McGovern, 2015; Thomasgard and Collins, 2003; and Žorga, et al., 2001. Had this literature been identified earlier it would have contributed to the evidence table and map of supervision competencies.

By selecting a scoping review, the quality of the review and systematic search may have suffered. Critical appraisals are not a part of the scoping review process. While each article was read in its entirety, the study would have benefitted from a team of reviewers completing critical appraisals on each of the selected articles. Additionally, it was challenging to weight quality across empirical, conceptual, and grey literatures. High quality empirical literature cannot be accurately compared with high quality conceptual literature. Therefore, literature in the high-quality category was treated as contributing equally quality data. Despite these limitations, including a broad range of studies likely led to more descriptive data than including a single literature type.

\section{CONCLUSIONS AND IMPLICATIONS FOR OCCUPATIONAL THERAPY EDUCATION}

This is the first known study of its kind to identify peer supervision competencies that pertain to graduate-level OT students. Findings suggest OT peer supervision competencies center on skillful relationship abilities as supervision skills are not innate, not dependent on clinical skill, and typically need to be taught. This scoping review extends supervision roles, responsibilities, and skills to graduate-level OT students by identifying competencies to enhance peer supervision relationships. Providing students with the opportunity to try out supervision is in line with previous recommendations that OT education should provide opportunities for students to practice behaviors of autonomy, assertiveness, self-directed learning, and conflict management so that they 
will be able to actualize those skills as professionals (Yerxa, 1975). Students are thus, acknowledged as occupational beings, adapting to the roles and responsibilities of supervision by participating in peer supervision activities. Peer supervision, as an occupation, represents domain and process. Utilizing peer supervision in OT education may provide a means and an outcome of teaching students to become OT supervisors. However, peer supervision is an under researched resource for enhancing learning experiences, therefore additional studies are needed in this area.

\section{References}

Abedin, Z., Biskup, E. Silet, K., Garbutt, J.M., Kroenke, K. Feldman, M.D., . . . Pincus, H.A. (2012). Deriving competencies for mentors of clinical and translational scholars. Clinical and Translational Science, 5(3), 273-280. https://doi.org/10.1111/j.1752-8062.2011.00366.x

Akhurst, J., \& Kelly, K. (2006). Peer group supervision as an adjunct to individual supervision: Optimising learning processes during psychologists' training. Psychology Teaching Review, 12(1), 3-15. Retrieved from http://www.bpsshop.org.uk/Psychology-Teaching-Review-Vol-12-No-1-2006P908.aspx

American Occupational Therapy Association. (2015). Philosophy of occupational therapy education. American Journal of Occupational Therapy, 69(Suppl. 3), 6913410053. https://doi.org/10.5014/ajot.2015.696S17

American Occupational Therapy Association. (2012). COE guidelines for an occupational therapy fieldwork experience - Level II. Retrieved from https://www.aota.org/ /media/Corporate/Files/EducationCareers/Educators/Field work/Levell//COE\%20Guidelines\%20for\%20an\%200ccupational\%20Therapy\%2 0Fieldwork\%20Experience\%20--\%20Level\%20ll--Final.pdf

Arksey, H., \& O'Malley, L. (2005). Scoping studies: Towards a methodological framework. International Journal of Social Research Methodology, 8, 19-32. https://doi.org/10.1080/1364557032000119616

Bassett, H., \& Lloyd, C. (2001). Occupational therapy in mental health: Managing stress and burnout. British Journal of Occupational Therapy, 64(8), 406-411. https://doi.org/10.1177/030802260106400807

Berg, C., Black, R., Fazio, L., Finlayson, M., Hooper, B., Krishnagiri, S., . . Rotert, D. (2009). Occupational therapy model curriculum. Bethesda, MD: American Occupational Therapy Association.

Berk, R.A, Berg, J., Mortimer, R., Walton-Moss, B., \& Yeo, T.P. (2005). Measuring the effectiveness of faculty mentoring relationships. Academic Medicine, 80(1), 66 71. https://doi.org/10.1097/00001888-200501000-00017

Berliner, D.C. (2002). Comment: Educational research: The hardest science of all. Educational Researcher, 31(8), 18-20. https://doi.org/10.3102/0013189X031008018

Borders, L. D. (1991). A systematic approach to peer group supervision. Journal of Counseling and Development, 69(3), 248-252. https://doi.org/10.1002/j.1556-6676.1991.tb01497.x 
Bussey-Jones, J., Bernstein, L., Higgins, S., Malebranche, D., Paranjape, A., Genao, I., ... Branch, W. (2006). Repaving the road to academic success: The IMeRGE approach to peer mentoring. Academic Medicine, 81(7), 674-679. https://doi.org/10.1097/01.ACM.0000232425.27041.88

Chipchase, L.S., Buttrum, P.J., Dunwoodie, R., Hill, A.E., Mandrusiak, A., \& Moran, M. (2012). Characteristics of student preparedness for clinical learning: Clinical educator perspectives using the Delphi approach. BMC Medical Education, 12, 112. https://doi.org/10.1186/1472-6920-12-112

Cohen, G.L., Steele, C.M., \& Ross, L.D. (1999). The mentor's dilemma: Providing critical feedback across the racial divide. Personality and Social Psychology Bulletin, 25(10), 1302-1318. https://doi.org/10.1177/0146167299258011

Counselman, E.F., \& Weber, R.L. (2004). Organizing and maintaining peer supervision groups. International Journal of Group Psychotherapy, 54(2), 125-143. https://doi.org/10.1521/ijgp.54.2.125.40391

de Oliveira, C.A., de Franca Carvalho, C.P., Cespedes, I.C., de Oliveira, F., \& Le SueurMaluf, L. (2015). Peer mentoring program in an interprofessional and interdisciplinary curriculum in Brazil. Anatomical Sciences Education, 8(4), 338347. https://doi.org/10.1002/ase.1534

Farace, D. J., \& Frantzen, J. (1998, November). Perspectives on the design and transfer of scientific and technical information. GL'97 Conference Proceedings: Third International Conference on Grey Literature, Luxembourg.

Fink, L. D. (2003). Creating significant learning experiences in college classrooms. San Francisco: Jossey-Bass.

Fleming, M., House, S., Hanson, V.S., Yu, L., Garbutt, J., McGee, R., . . Rubio, D.M. (2013). The Mentoring Competency Assessment: Validation of a new instrument to evaluate skills of research mentors. Academic Medicine, 88(7), 1002-1008. https://doi.org/10.1097/ACM.0b013e318295e298

Fone, S. (2006). Effective supervision for occupational therapists: The development and implementation of an information package. Australian Occupational Therapy Journal, 53(4), 277-283. https://doi.org/10.1111/j.1440-1630.2006.00581.x

Golia, G.M., \& McGovern, A.R. (2015). If you save me, I'll save you: The power of peer supervision in clinical training and professional development. British Journal of Social Work, 45(2), 634-650. https://doi.org/10.1093/bjsw/bct138

Hall, T., \& Cox, D. (2009). Clinical supervision: An appropriate term for physiotherapists? Learning in Health and Social Care, 8(4), 282-291. https://doi.org/10.1111/j.1473-6861.2009.00226.x

Khan, K.S., Kunz, R., Kleijnen, J., \& Antes, G. (2003). Five steps to conducting a systematic review. Journal of the Royal Society of Medicine, 96(3), 118-121. https://doi.org/10.1177/014107680309600304

Leonard, C. \& Corr, C. (1998). Sources of stress and coping strategies in basic grade occupational therapists. British Journal of Occupational Therapy, 61(6), 257-262. https://doi.org/10.1177/030802269806100605

Levac, D., Colquhou, H., \& O'Brien, K.K. (2010). Scoping methodologies: Advancing the methodology. Implementation Science, 5(69), 1 - 9. https://doi.org/10.1186/1748-5908-5-69 
Lord, J.A., Mourtzanos, E., McLaren, K., Murray, S.B., Kimmel, R.J., \& Cowley, D.S. (2012). A peer mentoring group for junior clinician educators: Four years' experience. Academic Medicine, 87(3), 378-383. https://doi.org/10.1097/ACM.0b013e3182441615

Mallidou, A.A., Atherton, P., Chan, L., Frisch, N., Glegg, S., \& Scarrow, G. (2017). Protocol of a scoping review on knowledge translation competencies. Systematic Reviews, 6(93), 1-8. https://doi.org/10.1186/s13643-017-0481-z

Martin, P., Copley, J., \& Tyack, Z. (2014). Twelve tips for effective clinical supervision based on a narrative literature review and expert opinion. Medical Teacher, 36(3), 201-207. https://doi.org/10.3109/0142159X.2013.852166

Mays, N., Roberts, E., \& Popay, J. (2001). Synthesizing research evidence. In N. Fulop, P. Allen, A., Clarke, \& N. Black (Eds.), Studying the organization and delivery of health services: Research methods (pp. $188-219$ ). London: Routledge.

Milner, T., \& Bossers, A. (2005). Evaluation of an occupational therapy mentorship program. Canadian Journal of Occupational Therapy, 72(4), 205-211. https://doi.org/10.2182/cjot.05.0003

Moher, D., Liberati, A., Tetzlaff, J., Altman, D.G., \& The PRISMA Group (2009). Preferred reporting items for systematic reviews and meta-analyses: The PRISMA statement. PLOS Medicine, 6(7), e1000097. https://doi.org/10.1371/journal.pmed. 1000097

NVivo qualitative data analysis Software; QSR International Pty Ltd. Version 11, 2015.

Pfund, C., House, S., Spencer, K., Asquith, P., Carney, P., Masters, K.S., . . Fleming, M. (2013). A research mentor training curriculum for clinical and translational researchers. Clinical and Translational Science, 6(1), 26-33. https://doi.org/10.1111/cts.12009

Saucier, D., Paré, L., Côté, L., \& Baillargeon, L. (2012). How core competencies are taught during clinical supervision: Participatory action research in family medicine. Medical Education, 46(12), 1194-1205 1112p. https://doi.org/10.1111/medu.12017

Spence, S.H., Wilson, J., Kavanagh, D., Strong, J., \& Worrall, L. (2001). Clinical supervision in four mental health professions: A review of the evidence. Behaviour Change, 18(3), 135. https://doi.org/10.1375/bech.18.3.135

Stutz-Tannenbaum, P., \& Hooper, B. (2009). Creating congruence between identities as a fieldwork educator and a practitioner. Special Interest Section Quarterly: Education, 19(2), 1-4.

Sweeney, G., Webley, P., \& Treacher, A. (2001). Supervision in occupational therapy, Part 3: Accommodating the supervisor and the supervisee. The British Journal of Occupational Therapy, 64(9), 426-431. https://doi.org/10.1177/030802260106400902

Thomasgard, M., \& Collins, V. (2003). A comprehensive review of a cross-disciplinary, case-based peer supervision model. Families, Systems \& Health, 21(3), 305-320. https://doi.org/10.1037/1091-7527.21.3.305

What is Allied Health? (n.d.) Association of Schools of Allied Health Professions. Retrieved from http://www.asahp.org/what-is/ 
Wimpenny, K., Forsyth, K., Jones, C., Evans, E., \& Colley, J. (2006). Group reflective supervision: Thinking with theory to develop practice. British Journal of Occupational Therapy, 69(9), 423-428. https://doi.org/10.1177/030802260606900906

Yerxa, E.J. (1975). On being a member of a 'feminine' profession. American Journal of Occupational Therapy, 29(10), 597-599.

Žorga, S., Dekleva, B., \& Kobolt, A. (2001). The process of internal evaluation as a tool for improving peer supervision. International Journal for the Advancement of Counselling, 23(2), 151-162. https://doi.org/10.1023/a:1010642829067 


\section{APPENDIX A}

\section{Evidence Table of High Quality Articles}

\begin{tabular}{|c|c|c|c|c|}
\hline \multicolumn{5}{|c|}{$\begin{array}{l}\text { Table } 4 \\
\text { Evidence Table }\end{array}$} \\
\hline \multicolumn{5}{|c|}{ Peer Supervision } \\
\hline $\begin{array}{l}\text { Author/ } \\
\text { Year }\end{array}$ & Purpose & $\begin{array}{l}\text { Design/ } \\
\text { Approach }\end{array}$ & Methods & Results \\
\hline $\begin{array}{l}\text { (Lord et al., } \\
2012)\end{array}$ & $\begin{array}{l}\text { Study effect of } \\
\text { peer } \\
\text { mentoring } \\
\text { group (PMG) } \\
\text { among junior } \\
\text { faculty in } \\
\text { psychiatry at } \\
\text { Washington } \\
\text { Medical } \\
\text { Center. }\end{array}$ & $\begin{array}{l}\text { Pilot study } \\
\text { involving } \\
\text { interview, } \\
\text { observation, } \\
\text { and document } \\
\text { analysis. } \\
\text { (Empirical) }\end{array}$ & $\begin{array}{l}\text { PMG of } 6 \mathrm{Jr} \\
\text { Faculty \& } 1 \mathrm{Sr} \\
\text { Faculty that met } \\
\text { from 2006-2010 } \\
\text { (30 meetings } \\
\text { total). PMG } \\
\text { program was } \\
\text { evaluated by } \\
\text { an outside } \\
\text { research } \\
\text { consultant via } \\
\text { interview, } \\
\text { observation, } \\
\text { written } \\
\text { responses, and } \\
\text { document } \\
\text { critique. } \\
\\
\text { Survey thematic } \\
\text { analysis used to } \\
\text { support outside } \\
\text { researchers' } \\
\text { findings. }\end{array}$ & $\begin{array}{l}\text { PMGs increased } \\
\text { workplace satisfaction; } \\
\text { improved social } \\
\text { connection; increased } \\
\text { professional productivity } \\
\text { and personal } \\
\text { growth/development } \\
\text { through accountability, } \\
\text { collaboration, mutual } \\
\text { learning, support, and } \\
\text { information sharing; } \\
\text { synergy, collaboration, } \\
\text { and diversity of thought; } \\
\text { increased involvement in } \\
\text { professional activities; } \\
\text { opportunity for peer } \\
\text { discussions in a safe } \\
\text { environment; and } \\
\text { increased accountability } \\
\text { and motivation (p. 380). } \\
\text { Unintended and } \\
\text { undesired effects also } \\
\text { identified (p. 381). }\end{array}$ \\
\hline $\begin{array}{l}\text { (Milner \& } \\
\text { Bossers, } \\
2005 \text { ) }\end{array}$ & $\begin{array}{l}\text { To evaluate } \\
\text { the mentorship } \\
\text { program } \\
\text { offered within } \\
\text { the program in } \\
\text { OT curriculum } \\
\text { at The } \\
\text { University of } \\
\text { Western } \\
\text { Ontario. }\end{array}$ & $\begin{array}{l}\text { Explorative } \\
\text { Survey (Likert } \\
\text { scale and } \\
\text { open-ended } \\
\text { questions). } \\
\text { Thematic } \\
\text { Analysis. } \\
\text { (Empirical) }\end{array}$ & \begin{tabular}{|l} 
Mentors and \\
mentees from 4 \\
class cohorts \\
(1999-2002) \\
were surveyed \\
to assess \\
strengths, \\
weaknesses, \\
changes \\
needed, and \\
effectiveness of \\
a mentorship
\end{tabular} & $\begin{array}{l}\text { Strengths per mentees } \\
\text { (p. 208): } \\
\text {-Mentors as } \\
\text { resources/role models } \\
\text {-Supportive/positive } \\
\text { group dynamic } \\
\text {-Integrating theory into } \\
\text { practice } \\
\text {-Supportive environment } \\
\text { for discussions }\end{array}$ \\
\hline
\end{tabular}




\begin{tabular}{|c|c|c|c|c|}
\hline & & & $\begin{array}{l}\text { program. Three } \\
\text { cohorts } \\
\text { completed the } \\
\text { survey post- } \\
\text { experience. } \\
\text { One cohort was } \\
\text { surveyed mid } \\
\text { and post- } \\
\text { experience. A } \\
\text { total of } 179 \\
\text { surveys were } \\
\text { analyzed. } \\
\text { The surveys } \\
\text { used a 5-pt } \\
\text { Likert scale and } \\
\text { open-ended } \\
\text { questions. } \\
\text { Open-ended } \\
\text { responses were } \\
\text { coded, and } \\
\text { Likert scale } \\
\text { questions were } \\
\text { entered into an } \\
\text { SPSS database. } \\
\text { Descriptive } \\
\text { statistics } \\
\text { (Cronbach's } \\
\text { alpha and } \\
\text { interquartile } \\
\text { deviations) were } \\
\text { used to capture } \\
\text { consensus. }\end{array}$ & $\begin{array}{l}\text { Strengths per mentors } \\
\text { (p.209): } \\
\text {-Content is flexible } \\
\text {-Contact with practicing } \\
\text { clinician } \\
\text {-Feedback, support and } \\
\text { guidance } \\
\text {-Integrating theory into } \\
\text { practice } \\
\text { Weaknesses reported by } \\
\text { both groups. }\end{array}$ \\
\hline \multicolumn{5}{|c|}{ OT Clinical Education } \\
\hline $\begin{array}{l}\text { Author/ } \\
\text { Year }\end{array}$ & Purpose & $\begin{array}{l}\text { Design/ } \\
\text { Approach }\end{array}$ & Methods & Results \\
\hline $\begin{array}{l}\text { (Chipchase } \\
\text { et al., 2012) }\end{array}$ & $\begin{array}{l}\text { Deduce } \\
\text { characteristics } \\
\text { that } \\
\text { demonstrate } \\
\text { student } \\
\text { prepared-ness } \\
\text { for clinical } \\
\text { learning. }\end{array}$ & $\begin{array}{l}\text { Two round } \\
\text { Delphi study } \\
\text { (Empirical) }\end{array}$ & $\begin{array}{l}258 \text { clinical } \\
\text { educators of } \\
\text { OT, } \\
\text { physiotherapy, } \\
\text { and speech } \\
\text { pathology } \\
\text { responded to an } \\
\text { open-ended } \\
\text { questionnaire. }\end{array}$ & $\begin{array}{l}\text { Consensus was reached } \\
\text { on } 57 \text { characteristics of } \\
\text { the } 6 \text { themes (p. 5): } \\
\text { 1. Knowledge and } \\
\text { Understanding } \\
\text { (Cronbach's Alpha= } \\
0.85 \text { ) } \\
\text { 2. Willingness } \\
\text { (Cronbach's Alpha= } \\
0.89 \text { ) }\end{array}$ \\
\hline
\end{tabular}




\begin{tabular}{|c|c|c|c|c|}
\hline & & & $\begin{array}{l}\text { Results were } \\
\text { coded and } 6 \\
\text { themes with } 62 \\
\text { were identified. } \\
161 \text { participants } \\
\text { completed a } \\
\text { follow-up survey } \\
\text { in which they } \\
\text { ranked each } \\
\text { characteristic on } \\
\text { a 7-pt Likert } \\
\text { scale. } \\
\text { Descriptive } \\
\text { statistics } \\
\text { (Cronbach's } \\
\text { alpha and } \\
\text { interquartile } \\
\text { deviations) were } \\
\text { used to capture } \\
\text { consensus. }\end{array}$ & $\begin{array}{l}\text { 3. Professionalism } \\
\text { (Cronbach's Alpha= } \\
0.86) \\
\text { 4. Communication and } \\
\text { interaction } \\
\text { (Cronbach's Alpha= } \\
0.90) \\
\text { 5. Personal attributes } \\
\text { (Cronbach's Alpha= } \\
0.94) \\
\text { 6. Skills } \\
\text { (Cronbach's Alpha= } \\
0.88)\end{array}$ \\
\hline (Fone, 2006) & $\begin{array}{l}\text { Develop an } \\
\text { information } \\
\text { package to } \\
\text { assist OT staff } \\
\text { with } \\
\text { supervision }\end{array}$ & $\begin{array}{l}\text { Literature } \\
\text { review } \\
\text { (Conceptual) }\end{array}$ & $\begin{array}{l}\text { Supervision } \\
\text { practices were } \\
\text { reviewed in OT } \\
\text { department of a } \\
\text { university. } \\
\text { Literature } \\
\text { review: CINAHL } \\
\text { (1982-2004) } \\
\text { and Ovid } \\
\text { Medline (1982- } \\
\text { 2004) and } \\
\text { literature from } \\
\text { university } \\
\text { libraries. } \\
\text { Discussions } \\
\text { with } \\
\text { professional } \\
\text { bodies. }\end{array}$ & $\begin{array}{l}4 \text { concepts identified as } \\
\text { important to supervisors } \\
\text { and supervisees ( } p \text {. } \\
\text { 280): } \\
\text { 1. Guided reflective } \\
\text { thinking } \\
\text { 2. Adult learning } \\
\text { 3. Emotional intelligence } \\
\text { 4. Shifting skills }\end{array}$ \\
\hline $\begin{array}{l}\text { (AOTA, } \\
2014)\end{array}$ & $\begin{array}{l}\text { To provide a } \\
\text { set of } \\
\text { guidelines } \\
\text { regarding the } \\
\text { supervision, } \\
\text { roles, and } \\
\text { responsibilities }\end{array}$ & $\begin{array}{l}\text { Organization } \\
\text { statement } \\
\text { (Grey) }\end{array}$ & None reported. & $\begin{array}{l}\text { Supervision: } \\
\text {-Ensures the safe and } \\
\text { effective delivery } \\
\text { services } \\
\text {-Fosters professional } \\
\text { competence and } \\
\text { development }\end{array}$ \\
\hline
\end{tabular}




\begin{tabular}{|c|c|c|c|c|}
\hline & $\begin{array}{l}\text { of OT } \\
\text { practitioners }\end{array}$ & & & $\begin{array}{l}\text {-A cooperative process } \\
\text {-Aimed at establishing, } \\
\text { maintaining, or elevating } \\
\text { competence and } \\
\text { performance levels } \\
\text {-Based on mutual } \\
\text { understanding } \\
\text {-Promotes effective } \\
\text { utilization of resources } \\
\text {-Encourages creativity } \\
\text { and innovation } \\
\text {-Provides education and } \\
\text { support for goal } \\
\text { attainment }\end{array}$ \\
\hline $\begin{array}{l}\text { (Spence et } \\
\text { al., 2001) }\end{array}$ & $\begin{array}{l}\text { Identify } \\
\text { themes of } \\
\text { effective } \\
\text { supervision in } \\
\text { the } 4 \text { mental } \\
\text { health } \\
\text { professions } \\
\text { (OT, social } \\
\text { work, clinical } \\
\text { psychology, } \\
\text { and speech } \\
\text { pathology) }\end{array}$ & $\begin{array}{l}\text { Literature } \\
\text { review } \\
\text { (Conceptual) }\end{array}$ & $\begin{array}{l}\text { Review of } \\
\text { theoretical and } \\
\text { empirical } \\
\text { literature on } \\
\text { supervision in } 4 \\
\text { mental health } \\
\text { professions } \\
\text { (OT, social } \\
\text { work, clinical } \\
\text { psychology, and } \\
\text { speech } \\
\text { pathology) }\end{array}$ & $\begin{array}{l}\text { Themes of effective } \\
\text { supervision: } \\
\text {-Nurturing, supportive, } \\
\text { safe relationship } \\
\text {-Being respectful and } \\
\text { empathetic } \\
\text {-Facilitating emotional } \\
\text { processing and creativity } \\
\text {-Demonstrating interest } \\
\text { in/valuing of supervision } \\
\text {-Showing enthusiasm, } \\
\text { dynamism, and energy } \\
\text {-Availability, punctuality, } \\
\text { and accessibility } \\
\text {-Encouraging increased } \\
\text { responsibility } \\
\text {-Affirm rights and } \\
\text { strengths of supervisee } \\
\text { (empowerment) } \\
\text {-Supervisee takes active } \\
\text { role in relationship } \\
\text {-Being flexible and } \\
\text { adapting supervision } \\
\text { style } \\
\text {-Addressing process } \\
\text { issues } \\
\text {-Maintaining boundaries } \\
\text {-Identify core skills and } \\
\text { competencies for } \\
\text { practice } \\
\text {-Shared evaluation of } \\
\text { skills and competencies }\end{array}$ \\
\hline
\end{tabular}




\begin{tabular}{|c|c|c|c|c|}
\hline & & & & $\begin{array}{l}\text {-Providing specific } \\
\text { concrete examples } \\
\text {-Delivering constructive } \\
\text { nonjudgmental feedback } \\
\text { with clarity, sensitivity, } \\
\text { and concrete } \\
\text { suggestions } \\
\text {-Role modeling } \\
\text { competence and } \\
\text { professionalism } \\
\text {-Using a variety of } \\
\text { instructional methods } \\
\text {-Deciding on terms of } \\
\text { supervision prior to } \\
\text { onset: format, goals, } \\
\text { methods, } \\
\text { roles/responsibility, } \\
\text { record keeping, } \\
\text { evaluation methods, } \\
\text { feedback, and duration } \\
\text {-Agreeing on an agenda } \\
\text { for the session }\end{array}$ \\
\hline $\begin{array}{l}\text { (Sweeney et } \\
\text { al., 2001) }\end{array}$ & $\begin{array}{l}\text { To draw } \\
\text { together the } \\
\text { findings of } 2 \\
\text { reports on } \\
\text { experiences of } \\
\text { OT } \\
\text { supervisors } \\
\text { and } \\
\text { supervisees } \\
\text { and make } \\
\text { recommendati } \\
\text { ons for future } \\
\text { supervision } \\
\text { practices }\end{array}$ & $\begin{array}{l}\text { Summary of } \\
\text { findings from } \\
2 \text { prior } \\
\text { qualitative } \\
\text { investigations } \\
\text { (Empirical) }\end{array}$ & $\begin{array}{l}\text { Report 1: } 30 \text { OT } \\
\text { supervisors \& } \\
30 \text { OT student } \\
\text { supervisees } \\
\text { participated in } \\
\text { semi-structured } \\
\text { interviews } \\
\text { (female only). } \\
\text { Qualitative } \\
\text { analysis with } \\
\text { grounded theory }\end{array}$ & $\begin{array}{l}\text { Recommendations for } \\
\text { OT supervision } \\
\text { relationships: } \\
\text {-Training to supervise } \\
\text { and to receive } \\
\text { supervision with an } \\
\text { emphasis on process } \\
\text { issues, role and function } \\
\text { of supervision, strategies } \\
\text { and techniques, and } \\
\text { literature on supervision } \\
\text {-Examine and consider } \\
\text { supervision models from } \\
\text { other health professions } \\
\text { where research may be } \\
\text { more established } \\
\text {-Create a supervision } \\
\text { contract } \\
\text {-Provide feedback that is } \\
\text { clear, consistent, } \\
\text { balanced and specific } \\
\text {-Develop a supervision } \\
\text { style that promotes } \\
\text { structure and direction }\end{array}$ \\
\hline
\end{tabular}




\begin{tabular}{|c|c|c|c|c|}
\hline \multicolumn{5}{|l|}{ Allied Health } \\
\hline $\begin{array}{l}\text { Author/ } \\
\text { Year }\end{array}$ & Purpose & $\begin{array}{l}\text { Design/ } \\
\text { Approach }\end{array}$ & Methods & Results \\
\hline $\begin{array}{l}\text { (Abedin et } \\
\text { al., 2012) }\end{array}$ & $\begin{array}{l}\text { To derive a list } \\
\text { of actionable } \\
\text { mentoring } \\
\text { competencies } \\
\text { for junior } \\
\text { clinical and } \\
\text { translational } \\
(\mathrm{C} / \mathrm{T}) \text { science } \\
\text { investigators }\end{array}$ & $\begin{array}{l}\text { White paper } \\
\text { (Grey) }\end{array}$ & $\begin{array}{l}\text { Mixed Methods: } \\
\text { (1) Focus } \\
\text { groups with } 55 \\
\text { junior C/T } \\
\text { investigators } \\
\text { and } 44 \text { mentors } \\
\text { at } 4 \text { universities } \\
\text { (2) Literature } \\
\text { search on } \\
\text { mentoring } \\
\text { competencies } \\
\text { across a variety } \\
\text { of disciplines } \\
\text { (3) Reverse } \\
\text { engineering: } \\
\text { Panel of experts } \\
\text { translated C/T } \\
\text { competencies } \\
\text { into mentor } \\
\text { competencies } \\
\text { (4) Curricula } \\
\text { review: } \\
\text { Competencies } \\
\text { derived from } 2 \\
\text { existing } \\
\text { university } \\
\text { curricula } \\
\text { (5) Review of } \\
\text { mentor existing } \\
\text { evaluation forms } \\
\text { (6) Expert } \\
\text { Panel: Identify } \\
\text { themes, } \\
\text { actionable } \\
\text { competencies, } \\
\text { and examples }\end{array}$ & $\begin{array}{l}6 \text { thematic areas and } 19 \\
\text { competencies identified. } \\
\text { Thematic areas (p. 276- } \\
\text { 277): } \\
\text { 1. Communication and } \\
\text { Relationship } \\
\text { Management } \\
\text { 2. Psychosocial support } \\
\text { 3. Career and } \\
\text { professional } \\
\text { development } \\
\text { 4. Professional } \\
\text { Enculturation and } \\
\text { Scientific Integrity } \\
\text { 5. Research } \\
\text { Development } \\
\text { 6. C/T Investigator } \\
\text { Development }\end{array}$ \\
\hline $\begin{array}{l}\text { (Berk et al., } \\
2005)\end{array}$ & $\begin{array}{l}\text { Development } \\
\text { of } 2 \text { psycho- } \\
\text { metric tools: } \\
\text { The } \\
\text { Mentorship } \\
\text { Profile } \\
\text { Questionnaire }\end{array}$ & $\begin{array}{l}\text { Report on } \\
\text { creation of a } \\
\text { psychometric } \\
\text { instrument } \\
\text { (Conceptual) }\end{array}$ & $\begin{array}{l}\text { Ad Hoc Faculty } \\
\text { Mentoring } \\
\text { committee } \\
\text { investigated } \\
\text { faculty's } \\
\text { mentoring } \\
\text { activities to }\end{array}$ & $\begin{array}{l}\text { Development of } 2 \\
\text { psychometric tools: } \\
\text { The Mentorship Profile } \\
\text { Questionnaire (p. 70): } \\
\text { A mentee questionnaire } \\
\text { exploring mentor }\end{array}$ \\
\hline
\end{tabular}




\begin{tabular}{|c|c|c|c|c|}
\hline & $\begin{array}{l}\text { and The } \\
\text { Mentorship } \\
\text { Effective-ness } \\
\text { Scale. }\end{array}$ & & $\begin{array}{l}\text { develop a } \\
\text { definition of } \\
\text { mentorship and } \\
\text { identify specific } \\
\text { features and } \\
\text { tasks of } \\
\text { mentoring. The } \\
\text { committee } \\
\text { evaluated } \\
\text { existing } \\
\text { mentorship tools } \\
\text { to create two } \\
\text { mentorship } \\
\text { effectiveness } \\
\text { assessments. }\end{array}$ & $\begin{array}{l}\text { characteristics and } \\
\text { outcomes of the } \\
\text { mentoring relationship } \\
\\
\text { The Mentorship } \\
\text { Effectiveness Scale (p. } \\
71 \text { ): } \\
\text { A } 12 \text { item, } 6 \text {-pt Likert } \\
\text { scale that evaluates the } \\
12 \text { behavioral } \\
\text { characteristics of the } \\
\text { mentor }\end{array}$ \\
\hline $\begin{array}{l}\text { (Cohen et } \\
\text { al., 1999) }\end{array}$ & $\begin{array}{l}\text { Compare } \\
\text { reactions to } \\
\text { feedback } \\
\text { between black } \\
\text { and white } \\
\text { students }\end{array}$ & $\begin{array}{l}\text { 2x3 Factorial } \\
\text { Design } \\
\text { (Empirical) }\end{array}$ & $\begin{array}{l}\text { 2x3 Factorial } \\
\text { Design } \\
\text { compared race } \\
\text { (black, white) } \\
\text { with a criticism } \\
\text { condition } \\
\text { (unbuffered } \\
\text { criticism, } \\
\text { buffered } \\
\text { criticism, } \\
\text { buffered } \\
\text { criticism with } \\
\text { reassurance) } \\
\text { Study } 1 \\
\text { Measures: } 2 \times 3 \\
\text { ANCOVA } \\
\text { Study } 2 \\
\text { Measures: } 2 \times 3 \\
\text { ANOVA }\end{array}$ & $\begin{array}{l}\text { Both black and white } \\
\text { students responded } \\
\text { most favorable to } \\
\text { buffered criticism with } \\
\text { reassurance. Racial bias } \\
\text { was more likely to be } \\
\text { perceived in situations of } \\
\text { unbuffered criticism or } \\
\text { buffered criticism. }\end{array}$ \\
\hline $\begin{array}{l}\text { (Fleming et } \\
\text { al., 2013) }\end{array}$ & $\begin{array}{l}\text { To determine } \\
\text { the psycho- } \\
\text { metric } \\
\text { properties of } \\
\text { the Mentoring } \\
\text { Competency } \\
\text { Assessment } \\
\text { (MCA) }\end{array}$ & $\begin{array}{l}\text { Non- } \\
\text { randomized } \\
\text { pre-test/post- } \\
\text { test } \\
\text { (Empirical) }\end{array}$ & $\begin{array}{l}\text { MCA } \\
\text { administered to } \\
283 \text { mentor- } \\
\text { mentee pairs } \\
\text { from } 16 \\
\text { universities } \\
\text { participating in a } \\
\text { trial of a C/T } \\
\text { mentoring } \\
\text { curriculum. } \\
\text { Participants }\end{array}$ & $\begin{array}{l}\text { Results demonstrated } \\
\text { that MCA has reliability } \\
\text { and validity. Six } \\
\text { competencies and } 26 \\
\text { skills determined to have } \\
\text { an acceptable fit (p. } \\
\text { 1005): } \\
\text { 1. Maintaining effective } \\
\text { communication } \\
\text { 2. Aligning expectations }\end{array}$ \\
\hline
\end{tabular}




\begin{tabular}{|c|c|c|c|c|}
\hline & & & $\begin{array}{l}\text { completed a } \\
\text { pre-test, post- } \\
\text { test inventory on } \\
\text { their skills. } \\
\text { Measures: } \\
\text { Chi-square; } \\
\text { Comparative Fit } \\
\text { Index (CFI), } \\
\text { Tucker-Lewis } \\
\text { Index (TLI); } \\
\text { Root Mean } \\
\text { Square Error of } \\
\text { Approximation } \\
\text { (RMSEA) }\end{array}$ & $\begin{array}{l}\text { 3. Assessing } \\
\text { understanding } \\
\text { 4. Fostering } \\
\text { independence } \\
\text { 5. Addressing diversity } \\
6 \text {. Promoting } \\
\text { professional } \\
\text { development }\end{array}$ \\
\hline $\begin{array}{l}\text { (Hall \& Cox, } \\
\text { 2009) }\end{array}$ & $\begin{array}{l}\text { Study } \\
\text { experiences of } \\
\text { physiotherapis } \\
\text { ts engaged in } \\
\text { clinical } \\
\text { supervision }\end{array}$ & $\begin{array}{l}\text { Qualitative, } \\
\text { exploratory } \\
\text { study } \\
\text { (Empirical) }\end{array}$ & $\begin{array}{l}\text { Studied clinical } \\
\text { supervision } \\
\text { experiences of } \\
16 \\
\text { physiotherapists } \\
\text { at a District } \\
\text { General } \\
\text { Hospital. } \\
\text { Qualitative } \\
\text { approach } \\
\text { methods } \\
\text { included semi- } \\
\text { structured } \\
\text { audio-taped } \\
\text { interviews, } \\
\text { coding, and } \\
\text { content } \\
\text { analyses. }\end{array}$ & $\begin{array}{l}\text { The term "Clinical } \\
\text { supervision" is unclear, } \\
\text { thus inappropriate for } \\
\text { use with physical } \\
\text { therapists } \\
5 \text { themes (p. 286-287): } \\
\text { 1. Preparation for the } \\
\text { clinical supervision } \\
\text { process influences } \\
\text { understanding and } \\
\text { experience of clinical } \\
\text { supervision } \\
\text { 2. Availability of other } \\
\text { support and evaluations } \\
\text { confused the process } \\
\text { and detracted from } \\
\text { perceived need for } \\
\text { clinical supervision } \\
\text { 3. Clinical supervision } \\
\text { valued for professional } \\
\text { development, reflective } \\
\text { practice, and support } \\
\text { 4. Importance of the } \\
\text { relationship in } \\
\text { determining effective } \\
\text { supervision } \\
5 . \text { Confidence in the } \\
\text { clinical supervision } \\
\text { process affected by } \\
\text { understanding of } \\
\text { process }\end{array}$ \\
\hline
\end{tabular}




\begin{tabular}{|c|c|c|c|c|}
\hline $\begin{array}{l}\text { (Martin et } \\
\text { al., 2014) }\end{array}$ & $\begin{array}{l}\text { To outline } \\
\text { strategies for } \\
\text { effective } \\
\text { clinical } \\
\text { supervision }\end{array}$ & $\begin{array}{l}\text { Literature } \\
\text { review \& } \\
\text { expert } \\
\text { opinion } \\
\text { (Conceptual) }\end{array}$ & $\begin{array}{l}\text { Literature } \\
\text { review of clinical } \\
\text { supervision } \\
\text { nursing, } \\
\text { medicine, } \\
\text { psychology, } \\
\text { psychotherapy, } \\
\text { counselling, } \\
\text { social work, } \\
\text { physiotherapy, } \\
\text { OT and speech } \\
\text { pathology. } \\
\text { Review } \\
\text { supplemented } \\
\text { by expert } \\
\text { opinion. }\end{array}$ & $\begin{array}{l}\text { Resulted in a list of } 12 \\
\text { generalizable tips for } \\
\text { effective clinical } \\
\text { supervision (p. 202-205) } \\
\text { 1. Identifying a suitable } \\
\text { clinical supervisor } \\
\text { 2. Deciding on the most } \\
\text { suitable type of } \\
\text { supervision } \\
\text { 3. Establishing a } \\
\text { supervision } \\
\text { agreement/contract and } \\
\text { using a supervision } \\
\text { agenda } \\
\text { 4. Choosing a venue } \\
\text { away from the } \\
\text { supervisee's workplace } \\
\text { to conduct supervision } \\
\text { sessions } \\
\text { 5. Deciding on the } \\
\text { optimal meeting length } \\
\text { and frequency } \\
6 \text {. Using effective } \\
\text { communication and } \\
\text { feedback } \\
\text { 7. Facilitating reflective } \\
\text { practice } \\
\text { 8. Considering use of } \\
\text { more than one mode for } \\
\text { distance clinical } \\
\text { supervision } \\
\text { 9. Building a positive } \\
\text { supervisory relationship } \\
\text { 10. Separating clinical } \\
\text { supervision from line } \\
\text { management } \\
\text { 11. Undertaking training } \\
\text { in supervision } \\
\text { 12. Evaluating clinical } \\
\text { supervision }\end{array}$ \\
\hline $\begin{array}{l}\text { (Pfund et al., } \\
2013 \text { ) }\end{array}$ & $\begin{array}{l}\text { To design and } \\
\text { evaluate a } \\
\text { research } \\
\text { mentor } \\
\text { training } \\
\text { curriculum for }\end{array}$ & $\begin{array}{l}\text { Program } \\
\text { analysis in } \\
\text { which study } \\
\text { participants } \\
\text { were } \\
\text { randomized }\end{array}$ & $\begin{array}{l}144 \text { mentors at } \\
16 \text { academic } \\
\text { institutions } \\
\text { participated in a } \\
\text { standardized } \\
\text { mentoring }\end{array}$ & $\begin{array}{l}88 \% \text { had high levels of } \\
\text { satisfaction } \\
90 \% \text { would recommend } \\
\text { training to a colleague }\end{array}$ \\
\hline
\end{tabular}




\begin{tabular}{|c|c|c|c|c|}
\hline & $\begin{array}{l}\text { clinical and } \\
\text { translational } \\
\text { researchers. }\end{array}$ & $\begin{array}{l}\text { (trial) and } \\
\text { then } \\
\text { surveyed } \\
\text { (Likert scale } \\
\text { items) } \\
\text { (Empirical) }\end{array}$ & $\begin{array}{l}\text { curriculum. } \\
\text { Survey } \\
\text { questions and } \\
\text { written } \\
\text { reflections were } \\
\text { gathered from } \\
\text { participants } \\
\text { after curriculum } \\
\text { completion } \\
\text { (94\% response } \\
\text { rate). }\end{array}$ & $\begin{array}{l}\text { Significant learning gains } \\
\text { in the } 6 \text { mentoring } \\
\text { competencies (p. 29): } \\
\text { 1. Maintaining effective } \\
\text { communication } \\
\text { 2. Aligning expectations } \\
\text { 3. Assessing } \\
\text { understanding } \\
\text { 4. Fostering } \\
\text { independence } \\
\text { 5. Addressing diversity } \\
\text { 6. Promoting } \\
\text { professional } \\
\text { development }\end{array}$ \\
\hline $\begin{array}{l}\text { (Saucier et } \\
\text { al., 2012) }\end{array}$ & $\begin{array}{l}\text { Explore } \\
\text { whether core } \\
\text { competencies } \\
\text { are addressed } \\
\text { by clinical } \\
\text { supervision at } \\
\text { a family } \\
\text { medicine } \\
\text { residency } \\
\text { program }\end{array}$ & $\begin{array}{l}\text { Participatory } \\
\text { action } \\
\text { research } \\
\text { design } \\
\text { (Empirical) }\end{array}$ & $\begin{array}{l}6 \text { junior } \\
\text { residents and } \\
11 \text { preceptors } \\
\text { from Laval } \\
\text { University's } \\
\text { Family Medicine } \\
\text { Residency } \\
\text { Programme, } \\
\text { Quebec City, } \\
\text { participated in } 3 \\
\text { focus groups } \\
\text { over } 9 \text { months. } \\
\text { Qualitative data } \\
\text { analysis } \\
\text { included } \\
\text { thematic content } \\
\text { analysis, } \\
\text { triangulation of } \\
\text { participants, } \\
\text { methods and } \\
\text { researchers, } \\
\text { and member } \\
\text { checking. }\end{array}$ & $\begin{array}{l}4 \text { themes identified ( } p \text {. } \\
\text { 1198-1199): } \\
\text { 1. Core competencies } \\
\text { were addressed... . but } \\
\text { implicitly, intuitively, and } \\
\text { often unconsciously } \\
\text { 2. Core competencies } \\
\text { must be known and } \\
\text { valued to be addressed. } \\
\text { 3. Discussion of core } \\
\text { competencies occurs in } \\
\text { a constant adaptation to } \\
\text { numerous contextual } \\
\text { factors } \\
\text { 4. Coherence with other } \\
\text { elements in the } \\
\text { curriculum contributed to } \\
\text { the integration of core } \\
\text { competencies } \\
\text { 6 challenges to } \\
\text { integration of core } \\
\text { competencies identified } \\
\text { (p. 1200-1201): } \\
\text { 1) Recognition of each } \\
\text { actor's specific role in a } \\
\text { dynamic interaction } \\
\text { 2) Resident's active } \\
\text { engagement } \\
\text { 3) Establishment of a } \\
\text { relationship based on } \\
\text { mutual trust }\end{array}$ \\
\hline
\end{tabular}




\begin{tabular}{|l|l|l|l|}
\hline & & & $\begin{array}{l}\text { 4) Finding common } \\
\text { ground around core } \\
\text { competencies } \\
\end{array}$ \\
& & $\begin{array}{l}\text { 5) Promotion of the } \\
\text { resident's autonomy } \\
\end{array}$ & $\begin{array}{l}\text { 6. Taking into account } \\
\text { the resident's level of } \\
\text { professional maturation }\end{array}$ \\
\hline
\end{tabular}

